\title{
Highly heterogeneous mantle caused by two-stage mantle metasomatism: Evidence from the phonotephrite dykes in the northwestern Tarim Large Igneous Province
}

\author{
BOWEN WEI ${ }^{1}$, ZHAOCHONG ZHANG $^{1 *}$, ZHIGUO \\ CHENG $^{1}$, WEILIANG KONG ${ }^{1}$, BINGXIANG LIU $^{1}$ \\ ${ }^{1}$ State Key Laboratory of Geological Processes and Mineral \\ Resources, China University of Geosciences, Beijing 100083, \\ China (Correspondence: zczhang@cugb.edu.cn)
}

Small volume of alkali basaltic magmas may reflect deep mantle dynamic processes. However, whether the source of alkali basaltic magmas is enriched lithospheric or asthospheric mantle is still highly debated. Here, we report the petrological and geochemical characteristics of the phonotephrite dykes in the northwest margin of the Tarim Basin in Xinjiang, China. The dykes are classified into pyroxene-bearing phonotephrite and kaersutite-bearing phonotephrite. The two types of phonotephrite have porphyritic textures with dominated clinopyroxene phenocryst and amphibole phenocryst, respectively. The high contents of $\mathrm{TiO}_{2}$ (2.17-4.36 wt.\%), $\mathrm{Na}_{2} \mathrm{O}$ (3.07-5.49 wt.\%) and incompatible trace elements with low $\mathrm{Mg \#}(<50)$ and depleted $\mathrm{Sr}-\mathrm{Nd}$ isotope data $\left(\left({ }^{87} \mathrm{Sr} /{ }^{86} \mathrm{Sr}\right) \mathrm{t}(\mathrm{t}=275 \mathrm{Ma})=0.70516\right.$ 0.70566 and $\left.\varepsilon_{\mathrm{Nd}}(\mathrm{t})=-0.23-+2.06\right)$ observed in phonotephrites are similar to those of the tephrites and lamprophyres in the studied area, which indicate an enriched mantle source. Compared with the major elements contents observed from petrological experiment, it can be inferred that Ti-enriched components have been involved in the mantle source. By simulating the partial melting process, it is concluded that the phonotephrites dykes, together with tephrites and lamprophyres, were generated by low degree partial melting of a heterogeneously mixed mantle source (carbonated mantle + pyroxenite (eclogite)/amphibolite). In combination with the incompatible element ratios and the modeling results, the highly heterogeneous mantle sources may be the result of two stage of mantle enrichment and metasomatism: At the first stage, fluid-related metasomatism occurred in the southward subduction of South Tianshan ocean in early Middle Paleozoic as evidence by carbonated mantle. At the second stage, with the fusible component waning over time, metasomatic veins formed by the low-degree melts from asthenosphere in the Early Permian further enriched the mantle again which reflected by the depleted $\mathrm{Sr}-\mathrm{Nd}$ isotope data with highly incompatible element contents.

Key words: Tarim Large Igneous Province; Mantle heterogeneity; Plume/subduction metasomatism 